quartz-fibre instrument might be devised, and perhaps it might contain its own recording apparatus in a compact form, so as to make registration a much easier and less cumbrous business than it has been hitherto.

When so much is unknown it is a mistake to begin by observing with too great intricacy of detail. The salient features should be first obtained, and then attention directed to the minutiæ; but one of the first things to do is to arrange that every swing in the curve shall mean a swing of atmospheric potential, and not a mere excursion of a heavy needle.

I hope that the energy, skill, and judgment of the various observers in the States, and of Mr. Mendenhall, the author of this valuable report, may be utilised through the resources of the U.S. Government by the inauguration of a fresh series of observations under somewhat different conditions, and without the hamper of any immediately specified practical object.

OLIVER J. LODGE.

\section{THE PRESERVATION OF THE NATIVE BIRDS OF NEW ZEALAND.}

$\mathrm{I}$ our issue of September I6 last year (vol. xlvi. p. 502) we printed an excellent memorandum drawn up by Lord Onslow, late Governor of New Zealand, relating to a proposal for the preservation of the native birds of that colony by setting apart two islands for this purpose, namely, I.ittle Barrier or Hauturn Island in the north, and Resolution Island in the south. As regards the first of these islands, we have lately received a copy of the report by Mr. Henry Wright (addressed to the Hon. John Ballance, Premier of New Zealand) upon the subject. According to Mr. Wright, Hauturn Island, in the Guif of Hauraki, which is almost circular in shape, and contains an area of from 9000 to 10,000 acres, rising in the middle to an elevation of about 2000 feet, is very well adapted for the purpose required. Writing with a thorough knowledge of all the north island, Mr. Wright is able to say that there is no other part of it where the native birds are to be found in anything like such profusion and variety. He gives a list of forty species to be met with within its limits, and mentions as particular varieties the stitch-bird or kotihe (Pogonornis cincta) and the large dark kiwi (Apteryx bulleri) as both found there. There are slight difficulties in the way of the project, such as the presence of about a dozen Maoris now living on the island, and of a claimant for the timber, which, in the shape of kauri pine (Dammara australis), is present in large quantities. There are no Weka Rails (Ocydromus) in the island to destroy the birds' eggs; and there are no bees, which, for some reasons, are considered to be highly inimical to the native birds in New Zealand. The wild pigs, formerly numerous, have been killed out; and the mutton-bird (CEstrelata gouldi), the young of which were formerly eaten by the pigs, will consequently be able to breed again undisturbed. Cats unfortunately are very numerous, but Mr. $\mathrm{W}$ right proposes to offer at once a reward for their destruction, which is, of course, of great importance.

Mr. Wright's report seems quite convincing as to the suitability of Hauturn Island for the object in view, but we regret to hear that some difficulties have arisen in the Parliament of New Zealand as to the appropriation of the funds required for the purpose.

Lord Onsiow, however, is not disposed to let the matter drop, and will, we are sure, be strongly supported by Lord Glasgow, the present Governor of New Zealand, in carrying the matter to a successful issue. The Council of the Zoological Society of London, whose attention has been called to the subject, have passed in its favour the following resolutions, which were communicated to a general meeting of that body on the I6th inst.

(I) The council of the Society have learnt with great NO. I 2 I 7 , VOL. 47 ] satisfaction the steps that were proposed to be taken by the Earl of Onslow, when Governor of New Zealand, and by the Houses of General Assembly for the preservation of the native birds of New Zealand, by reserving certain small islands suitable for the purpose, and by affording the birds special protection on these islands.

(2) The council much regret to hear that difficulties have been encountered in carrying out this plan as regards one of these islands (Little Barrier Island), and trust that the Government of New Zealand may be induced to take the necessary steps to overcome these difficulties and to carry out this excellent scheme in its entirety.

(3) The council venture to suggest that besides the native birds to be protected in these reserves shelter should also be afforded to the remarkable Saurian, the Tuatera Lizard (Sphenodon punctatus), which is at present restricted to some small islands on the north coast of New Zealand, in the Bay of Plenty.

These resolutions have been communicated to the present Governor of New Zealand, and will, we trust, be of some assistance to him in inducing his Ministers to carry this excellent scheme into execution.

\section{THE EARTHQUAKES IN ZANTE.}

THE following is a list of the shocks of earthquake at Zante, compiled from telegrams published in the Times and Standard:-January $3 \mathrm{r}$, at daybreak, the most destructive earthquake, of which, however, some warning must have been given, if we may judge from the comparatively small loss of life. Other slighter shocks followed during the day. February I, 2 a.m., another severe shock, felt also in Cephalonia. February 2 , two more violent shocks, one of which caused some fresh damage. February 3, further shocks, but less frequent and violent. February 5, another violent shock. February 6 , continued shocks of slight intensity, followed by three more severe ones in the afternoon and evening. February 7 , another violent shock in the morning, resulting in but little additional damage. February 8 , some slight shocks. February Io, some slight shocks in different districts. February II, I a.m., a somewhat severe shock, followed by a succession of shocks between 8 and 9 p.m. February I2, further shocks in the early morning, soon after midnight, and again at intervals during the day. February I 3 or I 4 , renewed slight shocks, accompanied by loud subterranean rumblings. The $A$ thens correspondent of the Times, telegraphing on February 20 , says : "The shocks of earthquake continue at Zante, with varying degrees of violence. No serious damage is reported, but those who are compelled to live in the half-ruined or insecure houses are exposed to frequent alarms." It is estimated that the total loss of property due to the shocks may exceed $£ 600,000$.

According to a telegram in the Times for February 6 , the tide in Venice on the evening of February I "ebbed so low as to leave several of the canals without water. The gondola traffic was interrupted at different points, and many of those craft were stranded. This phenomenon corresponded with the earthquakes at Zante and Cephalonia." A simple calculation will show, however, that this can hardly have been due to the principal shock. The straight line joining Zante and Venice passes almost directly up the Adriatic, and its length is roughly 720 miles. Taking the time between daybreak on January 31 and the evening of Feb. I at 36 hours, this would give for the sea-wave an average velocity of 20 miles an hour, corresponding to an average depth of about 30 feet, which is considerably less than the actual amount, the mean depth of the Adriatic being I Io fathoms.

Earthquakes are frequent in Zante, and sometimes very severe. One of the most destructive shocks, which occurred on October 30,1840 , is described by Ansted in 
his work on the Ionian Islands (pp. 4I 5-419) chiefly from the report of the Lord High Commissioner, Sir Howard Douglas. The prison was in this case also unroofed, and hardly a house in the town of Zante escaped some injury. All of the villages on, or bordering on, the plain suffered more or less, especially Sculikado, which was reduced to a heap of ruins. The total amount of damage done was estimated at not less than $£ 300,000$. The great earthquake was followed by a large number of others, some very severe, ninety-five being counted up to November 4. Ansted notes (pp. 368, 369) the curious fact that each of the Ionian Islands seems for the most part to have its own earthquakes, independently of the others. About the year I8I8, he says, all the sensible shocks in Cephalonia and Zante were tabulated, the record extending over two and a quarter years. "During this time thirty distinct and well-marked shocks were recorded in Cephalonia ; but in no case did the shocks in Zante, although nearly contemporaneous, absolutely coincide with them. In most cases an interval of some days, and almost always more than twenty-four hours, seems to have elapsed between the times of the disturbances in the two, although they are so near that in these days [1863] of long range, a cannon-shot fired from the one might reach to the other."

\section{NOTES.}

THE French Academy of Sciences has opened a subscription in support of the movement for the publication of the writings of Jean Servais Stas and the erection of a monument in his memory.

A meeting of delegates of the Academies of Science at Berlin, Göttingen, Leipzig, Munich, and Vienna was held on January 29, under the presidency of Prof. Ribbeck. The object of the meeting was to prepare the way for a sort of federal union of the various German scientific societies, so that they may be able to act together about important matters of common interest. A hope was expressed that a great international confederation of scientific societies might ultimately be formed.

Announcement has been made of the death, on February 2, I893, at Hendaye, in the Department of the Basses Pyrénées, in his sixty-eighth year, of M. Victor Aimé Léon Olphe-Galliard, author, among other works, of "Contributions à la Faune Ornithologique de l'Europe Occidentale," in forty livraisons (of which the last was published in 1892) giving an elaborate description of the birds not merely of Western but of almost the whole of Europe, to say nothing of allied species belonging to other countries. M. Olphe-Galliard (whose name few writers, even Frenchmen, spell correctly) was remarkable among his countrymen for his knowledge of other languages than his own, and his recognition of the works of foreign ornithologists stands out in great contrast with that accorded to them by most continental authors. He translated into French several valuable papers written in Swedish and other tongues as little known, thus bringing them before readers to whom they would have been otherwise inaccessible, while he still further showed his appreciation of foreign naturalists by introducing into his principal work portraits of Johann Friedrich Naumann and William Macgillivray as the representative ornithologists of Germany and Great Britain. The earliest performance by which $M$. OlpheGalliard will be remembered was his description in the Annales of the Nalional Society of Lyon's for 1852 of the interesting Algerian bird which he called Erithacus Monssieri, after a French army-surgeon of that name who had recognised it as a new species in 1846 . In the following year specimens of it were procured by the late Mr. Louis Fraser, and placed in the British

$$
\text { NO } 1217, \text { VOL. } 47]
$$

Museum, but they met no kind reception there then, or even later, for the species finds itself in the Catalogue of Birds (vii. p. 2o) far removed from what all naturalists who have observed it in life declare to be its nearest relations-the Stonechats or the Redstarts-and shot into the rubbish-hole placarded Timeliidce, where no one would ever think of looking for it. M. Olphe-Galliard's latest publication consisted of letters addressed to him by the somewhat eccentric Christian I,udwig Brehm, which appeared in the Ornithologisches Fahrbuch for 1892 .

A meEting of conchologists is to be held at 67 , Chancery Lane, on Monday, February 27, at $8 \mathrm{p} . \mathrm{m}$., for the purpose of founding a "Malacological Society of London."

THE Geologists' Association has arranged for a visit of the members to the British Museum (Natural History), Cromwell Road, on March I8, when Mr. W. Carruthers will give a demonstration on "Gymnosperms from the Devonian to the present time." There will be an excursion to Norwich, Cromer, and Lowestoft at Easter.

Some admirable suggestions for the guidance of teachers of evening classes in wood-working under the direction of County Councils have been prepared by the Examination Board and Committee of the City and Guilds of London Institute. The suggestions relate to drawing lessons, object lessons, and bench work lessons.

THE type of weather during the past week has undergone but little change from that of the preceding week. Anticyclonic areas lay over Scandinavia and Spain, and low pressure systems continued to skirt our north and west coasts. The general conditions, however, were much qúieter, although a deep depression reached the west of Ireland on Sunday, causing gales on our western coasts. On Tuesday a large and important disturbance arrived over the south-west of England from off the Atlantic, and the wind circulation around its central area was complete. The difference of barometric pressure was, however, by no means large in different parts of the kingdom, and consequently there was not much wind. The barometer fell as low as 28.7 inches over the centre of the cyclonic area, and later during the day the disturbance continued its passage across England, and was accompanied by heavy rain. Temperature continued high for the season, the daily maxima ranging generally from $45^{\circ}$ to $55^{\circ}$, while on Sunday, the rgth inst., the thermometer rose to $60^{\circ}$ in the inland parts of England. In London it reached $59^{\circ}$, which was a higher reading than had been recorded so early in the year since 1878 . The sky was exceptionally brilliant in the east and south-east on that day, but on the whole the air has been very damp throughout the week, and rainfall has been of almost daily occurrence. For the week ended the 18 th inst. the rainfall exceeded the mean in all districts, except in the east of England. In the west of Scotland and the south-west of England the excess was considerable. Bright sunshine only exceeded the normal amount in Ireland and the north and east of Scotland.

THE Pilot Chart of the North Atlantic Ocean for February, 1893, shows that the weather in the North Atlantic during January was not abnormally severe, and that the eastern part of the ocean was unusually free from storms. A map is given illustrating the great size and severity of the hurricane of December 22 last, which had moved rapidly from Hatteras in an east-north-east direction. At the time selected for illustration, when the centre lay in longitude $36^{\circ}$ west, the storm area covered the entire Atlantic from Labracior and Nova Scotia to Madeira, Portugal, and Ireland. Some very low barometer readings were recorded, the lowest being 27.75 inches. There was a large amount of ice during January along the coast of 